\title{
Reproductive potential of Spodoptera eridania (Stoll) (Lepidoptera: Noctuidae) in the laboratory: effect of multiple couples and the size
}

\author{
A. Specht *, D. G. Montezano ${ }^{b}$, D. R. Sosa-Gómez, S. V. Paula-Moraes ${ }^{a}$, \\ V. F. Roque-Specht $t^{d}$ and N. M. Barros ${ }^{b}$ \\ aAEmbrapa Cerrados, BR 020, Km 18, CP 08223, CEP 73310-970, Planaltina, DF, Brazil \\ 'bnstituto de Biotecnologia, Universidade de Caxias do Sul - UCS, CP 1352, CEP 95070-560, Caxias do Sul, RS, Brazil \\ ${ }^{\circ}$ Embrapa Soja, Rodovia Carlos John Strass, Distrito de Warta, CP 231, CEP 86001-970, Londrina, PR, Brazil \\ 'Faculdade UnB Planaltina, Universidade de Brasília - UnB, Área n 1 , Vila de Fatima, \\ CEP 73345-010, Planaltina, DF, Brazil \\ *e-mail: alexandre.specht@embrapa.br
}

Received: November 7, 2014 - Accepted: March 19, 2015 - Distributed: May 31, 2016

(With 2 figures)

\begin{abstract}
This study aimed to evaluate the effect of keeping three couples in the same cage, and the size of adults emerged from small, medium-sized and large pupae (278.67 mg; $333.20 \mathrm{mg}$ and $381.58 \mathrm{mg}$, respectively), on the reproductive potential of S. eridania (Stoll, 1782) adults, under controlled conditions $\left(25 \pm 1{ }^{\circ} \mathrm{C}, 70 \% \mathrm{RH}\right.$ and 14 hour photophase). We evaluated the survival, number of copulations, fecundity and fertility of the adult females. The survival of females from these different pupal sizes did not differ statistically, but the survival of males from large pupae was statistically shorter than from small pupae. Fecundity differed significantly and correlated positively with size. The number of effective copulations (espematophores) and fertility did not vary significantly with pupal size. Our results emphasize the importance of indicating the number of copulations and the size of the insects when reproductive parameters are compared.
\end{abstract}

Keywords: Southern armyworm, spermatophore, fertility, reproduction.

\section{Potencial reprodutivo de Spodoptera eridania (Stoll) (Lepidoptera: Noctuidae) em laboratório: efeito de múltiplos casais e do tamanho}

\begin{abstract}
Resumo
Este estudo objetivou avaliar o efeito de confinar três casais em cada gaiola e o tamanho de adultos emergidos de pupas pequenas, medias e grandes $(278,67 \mathrm{mg}, 333,20 \mathrm{mg}$ e $381,58 \mathrm{mg}$, respectivamente), sobre o potencial reprodutivo de S. eridania (Stoll, 1782), em condições controladas $\left(25 \pm 1^{\circ} \mathrm{C}, 70 \%\right.$ UR e 14 horas de fotofase). Avaliou-se a sobrevivência, o número de cópulas, fecundidade e fertilidade dos adultos. A sobrevivência não diferiu significativamente entre fêmeas provenientes de pupas de diferentes tamanhos, mas os machos oriundos de pupas grandes tiveram sobrevivência significativamente menor que os demais tamanhos. A fecundidade diferiu significativamente e correlacionou-se positivamente com o tamanho. O número de cópulas (espematóforos) e a fertilidade não variaram em função do peso pupal. Os resultados enfatizam a importância de indicar o número de cópulas e o tamanho dos insetos estudados para que comparações entre os parâmetros reprodutivos possam ser efetuadas.
\end{abstract}

Palavras-chave: lagarta militar do Sul, espermatóforo, fertilidade, reprodução.

\section{Introduction}

The genus Spodoptera Guenee, 1852 is cosmopolitan and includes most "military caterpillars" of great agricultural importance (Pogue, 2002). Spodoptera eridania (Stoll, 1782 ) is endemic to the Americas (Pogue, 2002), and its polyphagous larvae are associated with 202 host plants belonging to 58 plant families (Montezano et al., 2014). In addition to various native host plants, $S$. eridania larvae feed on invasive plants and crops such as alfalfa, cotton,

peanuts, sweet potato, onions, beans, tobacco, sunflower, manioc, quinoa, soy, tomatoes and oleaceous in general (Montezano et al., 2014).

Previous studies using Spodoptera frugiperda (J. E. Smith, 1797) reared in the laboratory have documented that the number of copulations in cages with multiple couples $(n=25)$ is twice greater (Milano et al., 2008) than the number of copulations in cages with only one couple 
(Juarez et al., 2012). Additionally, a previous study using S. eridania (Montezano et al., 2013) also demonstrated that multiple couples led to a greater number of copulations, thus increasing fecundity and fertility.

In addition to the number of couples kept in experimental cages, biology studies using $S$. eridania indicate that pupal weight may also have an influence on fecundity (e.g. Parra et al., 1977; Valverde and Sarmiento, 1987; Mattana and Foerster, 1988).

Considering the different factors influencing the fecundity of S. eridania, this study uses the same population and complements previous studies evaluating adults (Montezano et al., 2013) and immatures (Montezano et al., 2014). Our objective was to compare the effects of keeping multiple couples together, and pupal weight, on the fecundity and fertility of $S$. eridania adults.

\section{Material and Methods}

The experiments were carried out under controlled conditions (temperature $=25 \pm 1{ }^{\circ} \mathrm{C}, 70 \% \mathrm{RH}$ and $14 \mathrm{~h}$ photophase). Observations were made daily. Information about the origin of the insects, and rearing methodology, are described in detail in Montezano et al. (2014).

To assess the effects of pupal size on the reproductive parameters, 1,150 larvae were reared individually, in order to obtain small, medium and large pupae (Table 1). Adults that emerged concurrently were put into five cages, which comprised five repetitions, each containing three couples from each pupal size. However, because not enough adults emerged concomitantly from large pupae, only four cages were filled with adults of this size. The difference in weight between the sexes was maintained respecting the main differences displayed by the immature stages (Montezano et al., 2014). The experimental design was completely randomized.

After simultaneous emergence of three couples from each pupal size, adults were put into plastic cages $(10 \mathrm{~cm}$ diameter and $15 \mathrm{~cm}$ height) with top end closed using plastic film, internally lined with filter paper and containing long strips of filter paper to stimulate oviposition. The lower portion of the cage was closed with a Petri dish $(10.5 \mathrm{~cm}$ diameter), also lined with filter paper.

The food available to adults corresponded to the diet described by Hoffmann-Campo et al. (1985), based on honey (10 g), sorbic acid (1 g), Methylparaben ( $1 \mathrm{~g})$, sucrose
$(60 \mathrm{~g})$, and distilled water $(1000 \mathrm{~mL})$. All components were dissolved in distilled water and the resulting solution was kept under refrigeration $\left(7^{\circ} \mathrm{C}\right)$. Pilsen beer was added, on a daily basis, to the solution at a proportion of one-quarter, and made available to the insects in a $5 \mathrm{~cm}$ Petri dish lined with cotton wool. Furthermore, autoclaved water was provided for the hydration of the insects, in another $5 \mathrm{~cm}$ cotton lined Petri dish as described by Montezano et al. (2013).

The following items were exchanged daily: plastic films from the upper portion of the cage, strips of filter paper, filter paper covering the internal portion of the cages, food and distilled water. On occasion, adults were found between the filter paper and the wall of the cage, ovipositing on the wall. When this happened, all three couples were transferred to a new cage. During maintenance activities, the dead adults were removed and females were dissected to determine the number of spermatophores. We evaluated the number of copulations, the average fertility rate (average number of eggs per female) and longevity.

Fertility was examined by randomly removing at least 10 egg masses from small, medium and large couples, on the first, third, fifth and last (seventh) days of oviposition. The egg masses fixed on filter paper were individualized by cutting the paper and placing them in Petri dishes with the bottom lined with filter paper moistened with distilled water. To count the eggs, we carefully removed the scales that covered the eggs using a fine brush, and then placed them under a stereoscopic microscope for counting. The eggs were counted during egg mass identification and after hatching the neonates were removed and counted with the aid of a fine brush.

Weight of pupae, number of spermatophores and fecundity were analyzed using descriptive statistics such as calculation of means and standard deviations. The means of each parameter were compared using ANOVA with Tukey test (LSD) at $95 \%$ of confidence.

Longevity was assessed using Kaplan-Meier Survival Analysis (Kaplan and Meier, 1958). The significance of the differences (confidence range at $95 \%$ probability) between the mean survival of each treatment was tested using a logarithmic scale with multiple comparisons and Bonferroni correction.

Given that more than one couple was present in each cage, it was not possible to obtain individualized data on pre-, post- and oviposition of females.

Table 1. Mean weight (mg), standard deviation and range (minimum- maximum) of pupae that gave origin to the adults used to evaluate the reproductive parameters of Spodoptera eridania. Three couples were maintained per cage under controlled conditions $\left(25 \pm 1{ }^{\circ} \mathrm{C}, 70 \% \mathrm{RH}\right.$ and 14 hours of photophase).

\begin{tabular}{|c|c|c|c|c|c|}
\hline Pupal size & Cages* & & & & \\
\hline (Mg) & $\mathbf{N}$ & Mean \pm SD & Range & Mean \pm SD & Range \\
\hline Small & 5 & $278.7 \pm 14.75 \mathrm{C}$ & $249-297$ & $240.5 \pm 10.29 \mathrm{C}$ & $221-257$ \\
\hline Median & 5 & $333.2 \pm 8.38 \mathrm{~B}$ & $319-348$ & $276.6 \pm 13.98 \mathrm{~B}$ & $257-301$ \\
\hline Large & 4 & $381.6 \pm 22.42 \mathrm{~A}$ & $372-403$ & $323.8 \pm 12.53 \mathrm{~A}$ & $317-336$ \\
\hline
\end{tabular}

*Cages with three couples, insects emerged on the same day. Means with different letters differ significantly between each other, in each column (Tukey HSD, $\mathrm{P}<0.05$ ). 


\section{Results}

All females were fertilized once and up to four times, and the average number of copulations, represented by the number of spermatophores $(2.286 \pm 1066)$, did not vary significantly between couples of different sizes $(\mathrm{F}=0.659$, $\mathrm{P}=0.523$ ).

The average survival time did not differ significantly between small and medium sized males and females, but larger insects survived for shorter periods of time (Figure 1).

Size significantly influenced average fecundity $(\mathrm{F}=33.395, \mathrm{P}<0.001)$ : the mean number of eggs was $1,709.067 ; 2,044.2672,469.917$ for small, medium, and large couples, respectively (Figure 2).

There were no significant differences in fertility considering the interaction between dates and sizes $(\mathrm{F}=0.565, \mathrm{P}=0.758)$ and between sizes $(\mathrm{F}=0.165$, $\mathrm{P}=0.848$ ). However, fertility (hatching percentage) was significantly lower on the first day of oviposition $(\mathrm{F}=8.487$, $\mathrm{P}<0.001$ ) (Table 2). Additionally, it worth mentioning that most eggs from all egg masses were fertile and that only five small egg masses were completely infertile: an egg mass with 22 eggs (small couple) on the first day of oviposition; two egg masses with 43 eggs (average-sized couples) and 29 eggs (large couples) on the third day, one egg mass with 31 eggs (average sized couple) on the fifth day one egg mass with 11 eggs (small couples) on the seventh day. These values can be interpreted to mean that the values of fertility were not influenced by a possible absence of egg fertilization, which would be detected if a large portion of the egg masses were completely infertile, especially on the first day.

\section{Discussion}

By comparing the values obtained in this study with the results of Montezano et al. (2013), we conclude that the use of multiple couples at least doubled the number of copulation of $S$. eridania maintained under the same rearing conditions, regardless of moth size. These results are similar to the highest values of fertilization obtained in experiments using $S$. frugiperda when various couples were maintained in each cage $(\mathrm{N}=25)$ (Milano et al., 2008), and are higher than those obtained by Juárez et al. (2012), who evaluated different populations of the same species using only one couple per cage.

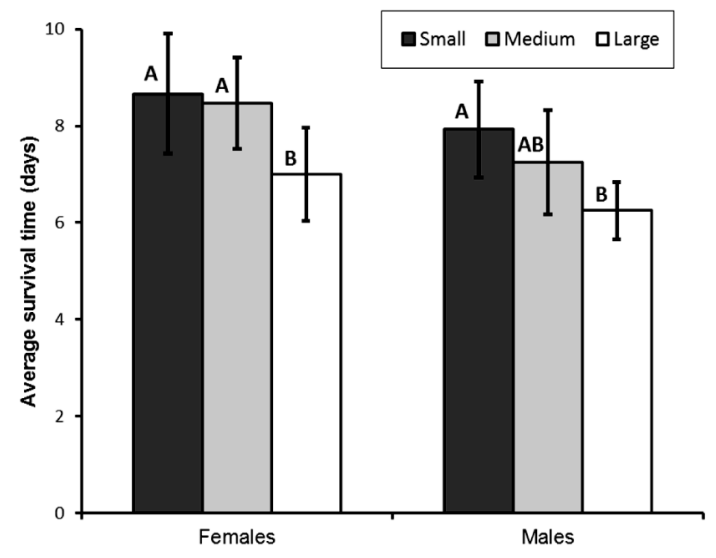

Figure 1. Average survival time (Kaplan-Meier) and confidence intervals of Spodoptera eridania moths emerged from small, medium-sized and large pupae. Three couples were maintained per cage under controlled conditions (25 $\pm 1{ }^{\circ} \mathrm{C}, 70 \% \mathrm{RH}$ and 14 hours of photophase). Means followed by the same letter do not differ significantly.

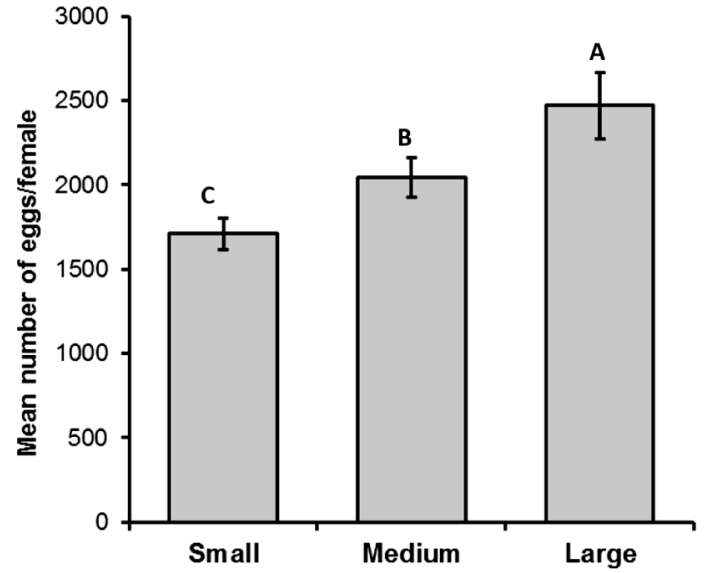

Figure 2. Average Fecundity and standard deviations of Spodoptera eridania adults from small, medium-sized and large pupae (see text). Three couples were maintained per cage under controlled conditions $\left(25 \pm 1{ }^{\circ} \mathrm{C}, 70 \% \mathrm{RH}\right.$ and 14 hours of photophase). Means followed by the same letter differ significantly from each other (Tukey HSD, $\mathrm{P}<0.05$ ).

Table 2. Number of egg masses, eggs and fertility (= hatching percentage - Mean and Standard Deviation) of Spodoptera eridania in different days of oviposition period. The data include moths from small, medium and large pupae (see text). Three couples were maintained per cage under controlled conditions $\left(25 \pm 1^{\circ} \mathrm{C}, 70 \% \mathrm{RH}\right.$ and 14 hours of photophase).

\begin{tabular}{cccc}
\hline Day of oviposition period & Egg masses & Eggs & Fertility (Mean \pm SD) \\
\hline First & 36 & 2,661 & $94.449 \mathrm{~B} \pm 7.719$ \\
Third & 61 & 6,709 & $98.649 \mathrm{~A} \pm 2.671$ \\
Fifth & 52 & 6,232 & $98.384 \mathrm{~A} \pm 2.561$ \\
Seventh & 37 & 2,553 & $97.508 \mathrm{~A} \pm 3.302$ \\
Total & 186 & 18,155 & $97.535 \mathrm{~A} \pm 4.470$ \\
\hline
\end{tabular}

Means with different letters differ significantly between each other, in each column (Tukey HSD, $\mathrm{P}<0.05$ ). 
Another very important aspect is that the fecundity of average-sized moths in our study (about 2,000 eggs) was higher than previously recorded for couples of similar weight that were mated once $(1,538.833)$ or twice $(1,798.000)$ (Montezano et al., 2013). The lower fecundity values observed when fewer couples (one or two) are maintained in a cage (Montezano et al., 2013) may be due to the fact that the period of preovipostion of these females is longer, given that they may not be fertilized immediately after emergence (Rogers and Marti Junior, 1997; Montezano et al., 2013). An alternative hypothesis is that females sometimes reject males, and copulation will be more likely when there are more males in the cage to choose from (Arnqvist and Nilsson, 2000).

Thus, considering that the pre- and oviposition periods of unfertilized females of Spodoptera may be expanded, thus decreasing fecundity (Kehat and Gordon, 1975; Ellis and Steele, 1982; Rogers and Marti Junior, 1997; Montezano et al., 2013, 2014), biology studies of Noctuidae that employ only one couple per cage (e.g. Teston et al., 2001; Santos et al., 2005; Specht et al., 2007, 2008, 2013) may have underestimated the reproductive and/or biotic potential of the species. In nature, females attract males with pheromones and through courtship behavior (Scoble, 1995; Young, 1997), being fertilized by several males immediately after emergence. Therefore, we postulate that to achieve the maximum reproductive potential in laboratory it is necessary to confine many insects in each cage.

On the other hand, in experiments using more than one couple per cage, important information such as the pre, post and oviposition periods, in addition to the fecundity and individual fertility (e.g. Milano et al., 2008) are lost. Also with respect to the formation of groups of individuals, it is difficult to reconcile simultaneous emergencies, especially when it is necessary to separate them into weight categories, as in the present study, or when the goal is to compare insects on different larval host plants etc. Such experiments should include hundreds of pupae. Having these difficulties in mind, we suggest an alternative: to pair a greater number of males with each individual female moth. This not only corresponds, at least in part, to a natural situation, creating the conditions for a greater number of copulations, but also enables the researcher to assess the periods of pre, post and oviposition, fecundity and fertility of each female individually.

The females that were kept in cages containing three couples (Figure 1) in the present study presented an average time of survival ( $\sim 7$ days) that was less than females of same size kept with only one male (10.8 days) (Montezano et al., 2013). The higher mean longevity of females kept in cages with a single male has two possible explanations: either females were not fertilized, or they were fertilized later with respect to females that were maintained in cages with three couples (Kehat and Gordon, 1975; Ellis and Steele, 1982; Rogers and Marti Junior, 1997; Montezano et al., 2013, 2014).

The fact that the fertility (though relatively high) of eggs from the first posture (Table 2) is significantly lower than from subsequent dates indicates that even though females are fertilized, the sperm is not able to reach the ova efficiently in the beginning of the oviposition period. This suggests that biology studies should consider performing fertility evaluations on different dates (e.g. Montezano et al., 2013, 2014).

The results of this study, together with those from Montezano et al. (2014) demonstrated the importance of female fertilization and size (pupal weight) on the fertility of S. eridania. Thus, future studies that aim to assess the maximum reproductive potential of species under given circumstances should take into consideration the rate of effective fertilization, number of copulations and pupal weight.

\section{Acknowledgements}

To the Conselho Nacional de Desenvolvimento Científico e Tecnológico (CNPq), for granting the Master's Fellowship to the second author (Process 557269/2010-5) and for financial assistance (Process 482627/2010-7).

\section{References}

ARNQVIST, G. and NILSSON, T., 2000. The evolution of polyandry: multiple mating and female fitness in insects. Animal Behaviour, vol. 60, no. 2, pp. 145-164. http://dx.doi.org/10.1006/ anbe.2000.1446. PMid:10973716.

ELLIS, P.E. and STEELE, G., 1982. The effect of delayed mating on the fecundity of females of Spodoptera littoralis (Boisduval) (Lepidoptera: Noctuidae). Bulletin of Entomological Research, vol. 72, no. 2, pp. 295-302. http://dx.doi.org/10.1017/ S0007485300010592.

HOFFMANN-CAMPO, C.B., OLIVEIRA, E.B. and MOSCARDI, F., 1985. Criação massal da lagarta da soja (Anticarsia gemmatalis). Londrina: Embrapa-SNPSo. 23 p. Documentos, no. 10.

JUÁREZ, M.L., MURÚA, M.G., GARCÍA, M.G., ONTIVERO, M., VERA, M.T., VILARDI, J.C., GROOT, A.T., CASTAGNARO, A.P., GASTAMINZA, G. and WILLINK, E., 2012. Host Association of Spodoptera frugiperda (Lepidoptera: Noctuidae) Corn and Rice Strains in Argentina, Brazil, and Paraguay. Journal of Economic Entomology, vol. 105, no. 2, pp. 573-582. http://dx.doi.org/10.1603/ EC11184. PMid:22606829.

KAPLAN, K.L. and MEIER, P., 1958. Non parametric estimation from incomplete observation. Journal of the American Statistical Association, vol. 53, no. 282, pp. 457-481. http://dx.doi.org/10.1 080/01621459.1958.10501452.

KEHAT, M. and GORDON, D., 1975. Mating, longevity, fertility and fecundity of the cotton leaf-worm, Spodoptera littoralis (Boisd.) (Lepidoptera: Noctuidae). Phytoparasitica, vol. 3, no. 2, pp. 87-102. http://dx.doi.org/10.1007/BF03158291.

MATTANA, A.L. and FOERSTER, L.A., 1988. Ciclo de vida de Spodoptera eridania (Cramer, 1782) (Lepidoptera: Noctuidae) em um novo hospedeiro, Bracatinga (Mimosa scabrella, Bentham) (Leguminosae). Anais da Sociedade Entomológica do Brasil, vol. 17, suppl., pp. 173-183.

MILANO, P., BERTI FILHO, E., PARRA, J.R. and CÔNSOLI, F.L., 2008. Influência da temperatura na frequência de cópula 
de Anticarsia gemmatalis (Hübner) e Spodoptera frugiperda (J.E. Smith) (Lepidoptera: Noctuidae). Neotropical Entomology, vol. 37, no. 5, pp. 528-535. http://dx.doi.org/10.1590/S1519566X2008000500005. PMid:19061037.

MONTEZANO, D.G., SPECHT, A., SOSA-GÓMEZ, D.R., ROQUE-SPECHT, V.F. and BARROS, N.M., 2013. Biotic potential and reproductive parameters of Spodoptera eridania (Stoll) (Lepidoptera, Noctuidae) in the laboratory. Revista Brasileira de Entomologia, vol. 57, no. 3, pp. 340-345. http:// dx.doi.org/10.1590/S0085-56262013005000026.

MONTEZANO, D.G., SPECHT, A., SOSA-GÓMEZ, D.R., ROQUE-SPECHT, V.F. and BARROS, N.M., 2014. Immature stages of the armyworm, Spodoptera eridania: developmental parameters and host plants. Journal of Insect Science, vol. 14, no. 238, pp. 1-11. PMid:25373148.

PARRA, J.R.P., PRECETTI, A.C.M. and KARSTEN JUNIOR, P., 1977. Aspectos biológicos de Spodoptera eridania (Cramer, 1782) (Lepidoptera: Noctuidae) em soja e algodão. Anais da Sociedade Entomológica do Brasil, vol. 6, no. 1, pp. 147-155.

POGUE, G.M., 2002. A world revision of the genus Spodoptera Guenée (Lepidoptera: Noctuidae). Memoirs of the American Entomological Society, vol. 43, pp. 1-202.

ROGERS, C.E. and MARTI JUNIOR, O.G., 1997. Once-mated beet armyworm (Lepidoptera: Noctuidae): effects of age at mating on fecundity, fertility, and longevity. Environmental Entomology, vol. 26, no. 3, pp. 585-590. http://dx.doi.org/10.1093/ee/26.3.585.

SANTOS, K.B., MENEGUIM, A.M. and NEVES, P.M.O.J., 2005. Biologia de Spodoptera eridania (Cramer) (Lepidoptera: Noctuidae) em diferentes hospedeiros. Neotropical Entomology, vol. 34, no. 6, pp. 903-910. http://dx.doi.org/10.1590/S1519$566 \times 2005000600005$

SCOBLE, M.J., 1995. The Lepidoptera form, function and diversity. New York: Oxford University Press. 404 p.

SPECHT, A., ANGULO, A.O., OLIVARES, T.S., FRONZA, E., ROQUE-SPECHT, V.F., VALDUGA, E., ALBRECHT, F., POLETTO, G. and BARROS, N.M., 2013. Life cycle of Agrotis malefida (Lepidoptera: Noctuidae): a diapausing cutworm. Zoologia, vol. 30, no. 4, pp. 371-378. http://dx.doi.org/10.1590/ S1984-46702013000400002.

SPECHT, A., FORMENTINI, A.C. and CORSEUIL, E., 2008. Bionomy of Anicla mahalpa Schaus, 1898 (Lepidoptera: Noctuidae: Noctuinae), in the laboratory. Brazilian Journal of Biology = Revista Brasileira de Biologia, vol. 68, no. 2, pp. 415-418. http:// dx.doi.org/10.1590/S1519-69842008000200026. PMid:18660973.

SPECHT, A., VOGT, T.G. and CORSEUIL, E., 2007. Biological aspects of Autoplusia egena (Guenée) (Lepidoptera: Noctuidae: Plusiinae). Neotropical Entomology, vol. 36, no. 1, pp. 1-4. http:// dx.doi.org/10.1590/S1519-566X2007000100001. PMid:17420856.

TESTON, J.A., SPECHT, A. and CORSEUIL, E., 2001. Biology of Anicla infecta (Ochsenheimer, 1816) (Lepidoptera, Noctuidae, Noctuinae), under laboratory conditions. Brazilian Journal of Biology $=$ Revista Brasileira de Biologia, vol. 61, no. 4, pp. 661-666. http://dx.doi.org/10.1590/S1519-69842001000400016. PMid:12071323.

VALVERDE, A. and SARMIENTO, J., 1987. (1986). Efecto de cuatro plantas hospedadoras em la biologia de Spodoptera eridania. Revista Peruana de Entomología, vol. 29, no. 1, pp. 55-60.

YOUNG, M., 1997. The natural history of moths. London: Poyser Natural History. 304 p. 